\title{
EFFECT OF MICROEMULSION ON LIBERATION OF INDOMETHACIN FROM HYDROPHILIC AND LIPOPHILIC GEL
}

\author{
Žabka, M. - Hukel'ová, M. - Čuchorová, M. - Starýchová, L. \\ Comenius University in Bratislava, Faculty of Pharmacy, Department \\ of Galenic Pharmacy
}

\begin{abstract}
The paper is focused on liberation of indomethacin from gels and the influence of microemulsion's presence in the system. Liberation of drug was performed in vitro through a semipermeable membrane and drug quantity was determined spectrophotometrically. Our results pointed out that the influence of microemulsion system on drug liberation depends on the gel selection. The presence of $\mathrm{o} / \mathrm{w}$ microemulsion in the lipophilic gel (aerosil in liquid paraffin) increased the released amount of the drug approximately $50 \%$. The liberation profile of indomethacin is better when the hydrophilic gel (carbopol) was used. Drug was released in higher amounts from hydrophilic gel comparised to the commercial gel. The presence of microemulsion in carbopol gel did not have any significant influence.
\end{abstract}

Keywords: microemulsion - indomethacin - in vitro liberation of drug

\section{INTRODUCTION}

Microemulsions and the other colloidal systems have received increased attention during the past few years. Microemulsion is defined as a dispersion consisting of oil, surfactant, cosurfactant and aqueous phase, which is a single optically isotropic and thermodynamically stable liquid solution with a droplet diameter usually in the range of 10- $100 \mathrm{~nm}$ (Chen, 2006). Microemulsions are suitable as drug delivery vehicles, because of their solubilizing capacity, transparency, thermodynamic stability, simple production, excellent rate of diffusion and absorption after in vivo administration and also for their ability to achieve the targeting of drugs (Žabka $\left.{ }^{1}, 2003\right)$. They can influence a drug release from the formulation to enhance absorption or to lower toxicity (Žabka $\left.{ }^{2}, 2003\right)$.

Limiting factors of microemulsion application are high content of tensides, biocompatibility between components, thermodynamic stability in the temperature range $4-40^{\circ} \mathrm{C}$, microemulsion sensibility on the presence of salts, etc. (Žabka, 1999). After topical application, microemulsions can interact with the stratum corneum by changing of structural rearrangement of its lipid layers and consequently increasing 
transdermal drug permeation and so act as penetration enhancers (Žabka\& Škoviera, 2003). Although microemulsions have been safely used to deliver drugs via the topical and the gastrointestinal routes to humans, intravenous injections have been studied as possible delivery vehicles for drug only in few studies (Žabka\&Benková, 1995;Sakaeda\& Hirano, 1998; Corswant et al., 1998).

Skin is a nature barrier and it is difficult for most of drugs to be delivered into or through it. There are some techniques that provide better penetration through this barrier, including the use of penetration enhancers, driving drug molecules into the skin under the influence of iontophoresis, disrupting the skin barrier by electroporation or sonophoresis, or encapsulating the drug in vesicular delivery systems (Maghraby, 2010).

The transdermal delivery of non-steroidal anti-inflammatory drugs has been explored as a potential method of avoiding the first pass effects and the gastric irritation, which occurs, when drugs are administered orally (Takahashi, 2002).

Indomethacin is a non-steroidal anti-inflammatory agent (NSAID) with analgesic and antipyretic activity. Its pharmacological effect is mediated through inhibition of the enzyme cyclooxygenase (COX), the enzyme responsible for catalyzes of the ratelimiting step in prostaglandin synthesis via the arachidonic acid pathway (drugbank.ca). In terms of solubility, indomethacin, white or yellow, crystalline powder is practically insoluble in water and sparingly soluble in alcohol (Eur.Ph.). It can be applied orally (capsules), intravenously (powder for solution), topically (gel) or rectally (suppositories). There are three drug dosage forms available in pharmaceutical market in Slovakia (adcc.sk): dermal aerodispersion (Elmetacin), suppositories (Indomethacin supp.) and dermal gel (Indomethacin 1\%, Indobene 1\%).

The aim of this work is to prove the effect of microemulsion system as a vehicle on the permeation of indomethacin from hydrophilic and lipophilic gel through the semipermeable membrane. The gelling agents such as carbomer or aerosilcan increase the viscosity of microemulsion and form microemulsion-based gel (Zhu, 2009).

\section{MATERIAL AND METHODS}

\section{Chemicals}

Indomethacin[1-( $p$-Chlorobenzoyl)-5-methoxy-2-methyl-1H-indole-3-acetic Acid] was from Merck KGaA (Darmstadt, Germany). Carbopol® 940 and Aerosil ${ }^{\circledR} 200$ were purchased from Sigma- Aldrich Chemical Co. (Steinheim, Germany). Indobene gel was from Ratiopharm GmbH (Germany). Purified water used for this study and all other reagents were in analytical grade. Liquid o/w microemulsion contained Tween 80, isopropyl myristate and water.

\section{Equipments}

Analytical weight Mettler Toledo (Switzerland), permeating apparatus - workplace of the Department of Galenic Pharmacy, Faculty of Pharmacy Comenius University (Bratislava, Slovakia), semipermeable membrane „Nephrophan“ produced by VEB Filmfabrik (Wolfen, Germany), thermostat U 10, viscometer - Viscotester VT 500 
(Berlin, Germany), spectrophotometer UV/VIS, Philips PV 9625 (Cambridge, Great Britain).

\section{Preparation of microemulsion}

Microemulsion was prepared by mixing of the suitable ratio of followed components water, oil and surfactant. For all microemulsions is characteristic clear appearance and high stability. The stability of microemulsion was observed for 3 months at room temperature.

\section{Preparation of gels}

The gel composition is summarized in Table 1. The liberation of indomethacin was evaluated from both types of gels, hydrogels $\left(\mathrm{Carbopol}^{\mathbb{}}{ }^{9} 940\right.$, Indobene ${ }^{\circledR}$ gel) and oleogel (Aerosil ${ }^{\circledR} 200$ ). Indobene ${ }^{\mathbb{B}}$ gel was commercially prepared.

Table 1. Composition of gels

\begin{tabular}{c|c|c|c|c} 
Gelling agent & $\begin{array}{c}\text { Conc. } \\
{[\%]}\end{array}$ & Solvents & $\begin{array}{c}\text { Other } \\
\text { additives }\end{array}$ & $\begin{array}{c}\text { Viscosity [Pa.s] } \\
\left(\mathrm{t}=21^{\circ} \mathrm{C} ; \mathrm{D}=6,45\right. \\
\left.\mathrm{s}^{-1}\right)\end{array}$ \\
\hline $\begin{array}{c}\text { Carbopol }^{\mathbb{R}} \\
940\end{array}$ & 0.50 & Water & triethanolamine & 9.89 \\
\hline Aerosi $^{\mathbb{B}} 200$ & 3.00 & $\begin{array}{c}\text { liquid } \\
\text { paraffin }\end{array}$ & - & 3.49 \\
\hline Indobene $^{\mathbb{B}}$ gel & Unknown & Water & triethanolamine & 16.30
\end{tabular}

\section{In vitro liberation of drug}

The amount of indomethacin corresponding to $1 \%$ of the sample was dissolved in the microemulsion. The examined gels were added to this dispersion. Ratio of microemulsion/gel was 1:4. Comparative samples contained only indomethacin dissolved in solvent and then dispersed in the gels. Drug release was carried out through the semipermeable membrane.

\section{RESULTS AND DISCUSSION}

In development of dermal drug delivery systems there is effort to reach adequate amount of permeated drug through the skin and optimal time of drug permeation. One strategy to enhance the permeation of drug consists in addition of chemical permeation enhancers into drug vehicle. The second possibility is the selection of suitable vehicle according to the drug chemical and physical properties. In the present study the effect of microemulsion as possible enhancer is proved in combination with two gels with different physical properties.

Indomethacin is not easy processed to the topical drug dosage form, because of its low solubility in water. It is sparingly soluble in alcohol. Indomethacin does not form homogeneous systems with clear appearance in hydrogels, and it is not easy released from them. Nevertheless, there is a considerable interest to prepare the topical drug dosage form that would provide therapeutical amount of released indomethacin which is strongly anti-inflammatory effective drug. 
The solubility of the drug in our microemulsion was determined as $6 \mathrm{mg}$ of indomethacin in $240 \mathrm{mg}$ of microemulsion.

Rheological behavior of gels was determined by viscometer. The relation between the shear rate (D) and the shear stress $(\tau)$ for all types of gels are shown as rheological curves (Fig. 1-3). Rheological measurements of the carbopol (Fig. 1) and the Indobene gel (Fig. 3) showed non- Newtonian behavior of slightly thixotropy very similar to pseudoplastic systems.

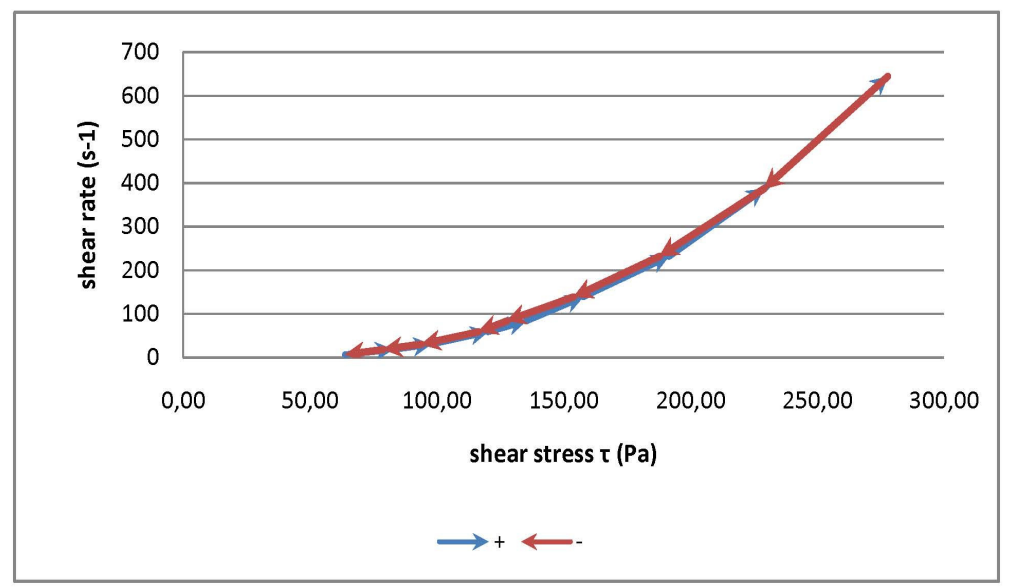

Figure 1. Flow curve of the carbopol gel

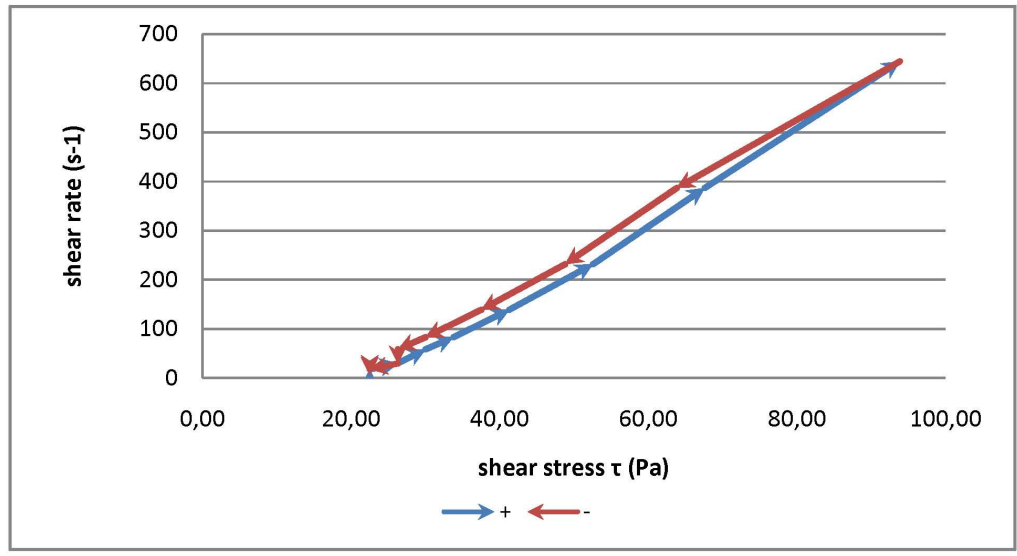

Figure 2. Flow curve of the aerosil gel 


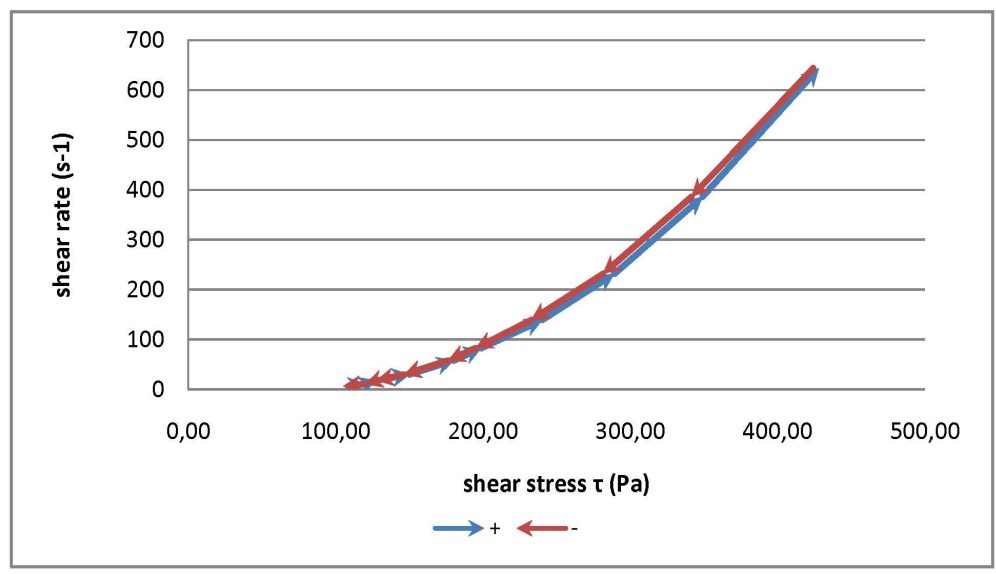

Figure 3. Flow curve of the Indobene gel

The flow curve of the aerosil gel shows a hysteresis loop (Fig. 2), therefore the system can be evaluated as thixotropic system. Thixotropy is a non-chemical isothermal gelsol-gel transformation (Aulton, 2005). Gel structure is destroyed by mechanical stress thus liquefying the system to sol. The specific rheological characteristics of thixotropic materials are of great interest in many areas of applied technology. The time necessary for the rearrangement of thixotropic structures depends on the actual system and may vary from few seconds to several days. The advantage of this system is easy application after shaking and high stability during the storage because of the higher viscosity.

The total amounts of released indomethacin from gels (carbopol, aerosil, Indobene) after $6 \mathrm{~h}$ of the liberation are shown in Fig. 4. The presence of microemulsion in the aerosil gel has increased the amount of drug by approximately $50 \%$. The amounts of the released drug from carbopol gel and from its mixture with microemulsion after $6 \mathrm{~h}$ were similar, which means, that this microemulsion type affects like permeation enhancer only in the lipophilic gel. Indobene gel, containing carbomer 980, triethanolamine, water, isopropyle alcohol, diisopropyladipate, was used as a reference for the comparison of liberation profile of indomethacin from examined gels. There was released 37\% less amount of indomethacin from the Indobene gel in comparison with carbopol gel after $6 \mathrm{~h}$. It can be noticed, that individually prepared hydrophilic carbopol gel neutralised by triethanol amine and in which isopropyl alcohol was used for dissolution of indomethacin in ratio $1: 1$ is better vehicle for the liberation of this drug either with or without the microemulsion. Liberation curves with standard errors of indomethacin from all gels are shown in Figure 5.

There is a statistically significant difference between the liberation profile of indomethacin from carbopol gel and carbopol gel with the content of microemulsion resulting from the Student's T test (calculated value is 0.015 ). 


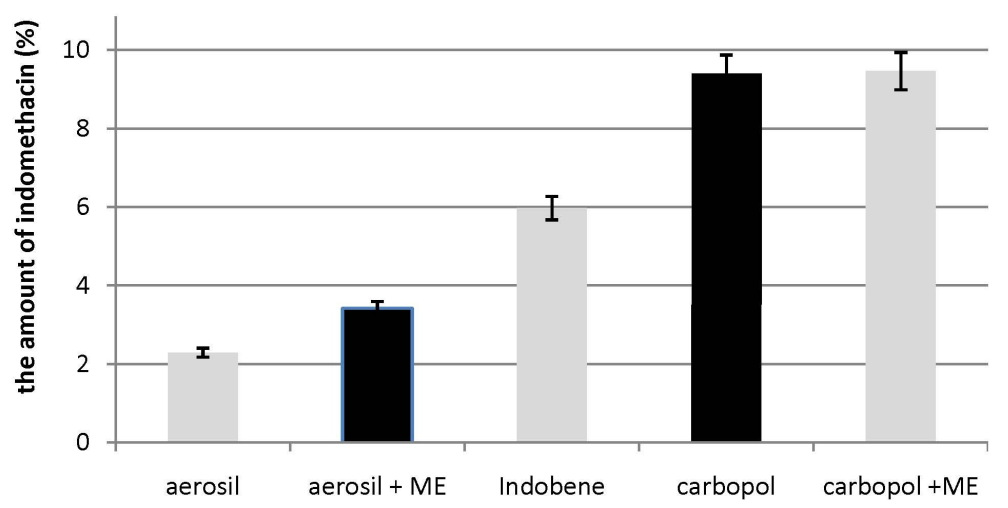

Figure 4. Cumulative amounts of released drug after $6 \mathrm{~h}$ from pure gels and gels with the content of microemulsion

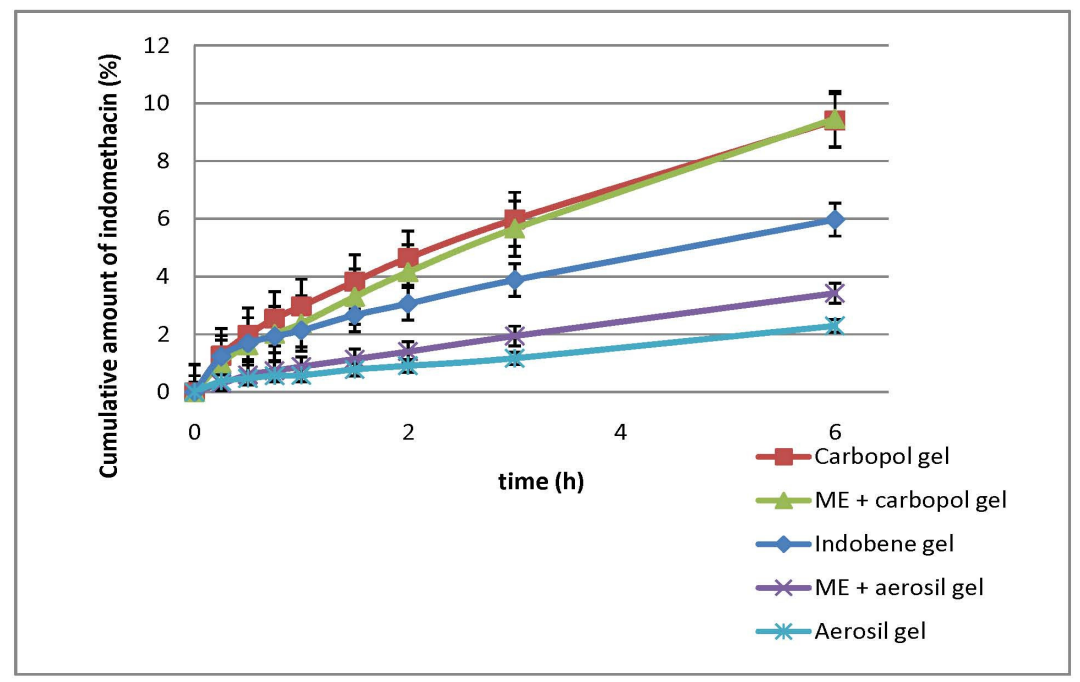

Figure 5. Liberation profiles of indomethacin from aerosil gel and carbopol gel, both with or without microemulsion and from Indobene gel

\section{CONCLUSION}

It can be concluded, that the liberation of indomethacin from lipophilic aerosil gel vehicle was lower in comparison with carbopol gel. Although the presence of the microemulsion has increased the released amounts of indomethacin, there were not reached such values as obtained from the liberation of the drug from hydrophilic carbopol gel. The influence of the microemulsion on the liberation of drug 
from carbopol gel was not significant. Prepared carbopol gel with or without microemulsion is more suitable for permeation of indomethacin than commercial Indobene gel.

\section{ACKNOWLEDGEMENTS}

This work was supported by research grants from Comenius University: UK/511/2012, UK/512/2012, UK/513/2012.

\section{REFERENCES}

Aulton ME. Aulton's Pharmaceutics: The design and manufacture of medicines. New York: Churchill Livingstone; 2007.

Corswant CP, Thoren P, Engstrom S. Triglyceride-based microemulsion for intravenous administration of sparingly soluble substances. J Pharm.Sci. 1998;87:200-208.

European Pharmacopoeia

(http://lib.njutcm.edu.cn/yaodian/ep/EP5.0/16_monographs/monographs_dk/Indometacin.pdf). Accessed February 2, $201 \overline{2}$.

Chen $\mathrm{H}$ et al. Microemulsion- based hydrogel formulation of ibuprofen for topical delivery. Int. J. Pharm. 2006;315:52-58.

Maghraby GM. Self-microemulsifying and microemulsion systems for transdermal delivery of indomethacin: Effect of phase transition. Colloids Surf B. 2010;75:595-600. Open Data Drug \& Drug Target Database

(http://www.drugbank.ca/drugs/DB00328). Revised September 24, 2011.Accessed January 2, 2012.

Sakaeda T, Hirano K. Effect of composition on biological fate of oil particles after intravenous injection of o/w lipid emulsions. J Drug Target. 1998;6:273-284.

Slovak central electronic database of pharmaceutical products

(http://www.adcc.sk/web/humanne-lieky/ucinna-latka/indometacin-5777.html).

Accessed January 2, 2012.

Takahashi A et al. Percutaneous absorption of non-steroidal anti-inflammatory drugs from in situ gelling xyloglucan formulations in rats. Int J Pharm. 2002;246:179-186.

Zhu W et al. Microemulsion-based hydrogel formulation of penciclovir for topical delivery. Int. J. Pharm. 2009;378:152-158. 
Žabka M, Benková M. Microemulsions containing local anesthetics: Part 6: Influence of microemulsion vehicle on in vitro effect of pentacaine. Pharmazie. 1995;50:703-744.

Žabka M, Muller RH, Hildebrand GE. Modern drug forms in pharmaceutical technology. Bratislava: Slovak Academic Press; 1999.

Žabka M, Škoviera F. Microemulsions as vehicles for transdermal permeation of drugs. Acta Fac Pharm Univ Comen. 2003;L:147-155

Žabka M. ${ }^{1}$ Colloidal drug delivery - Current state and perspective II. Microemulsions Thermodynamic aspects, formulation, production. Farm Obzor. 2003;72:64-68.

Žabka M. ${ }^{2}$ Colloidal drug delivery - Current state and perspective III: Microemulsions as drug delivery vehicles. Farm Obzor. 2003;72:87-92.

Registered: February 15, 2012

Accepted: June 6, 2012
PharmDr. Miroslava Hukel'ová

Comenius University in Bratislava Faculty of Pharmacy

Odbojárov 10

83232 Bratislava

Slovak Republic

hukelova@fpharm.uniba.sk

\title{
VPLYV MIKROEMULZIE NA LIBERÁCIU INDOMETACÍNU Z HYDROFILNÉHO A LIPOFILNÉHO GÉLU
}

\author{
Žabka, M. - Hukel'ová, M. - Čuchorová, M. - Starýchová, L.
}

Univerzita Komenského v Bratislave, Farmacutická fakulta, Katedra galenickej farmácie

Práca hodnotí uvol’ňovanie indometacínu z gélov a samotný vplyv mikroemulzie v systéme. Liberácia liečiva sa hodnotila $\mathrm{v}$ podmienkach in vitro cez semipermeabilnú membránu a množstvo uvol'neného liečiva sa stanovilo spektrofotometricky. Z výsledkov vyplýva, že vplyv mikroemulzného systému na liberáciu liečiva je modifikovaný použitým gélom. Prítomnost' mikroemulzie typu o/v v lipofilnom géle (aerosil v tekutom parafíne) zvýšila množstvo uvol’neného liečiva o $50 \%$. Liberačný profil indometacínu bol vhodnejší v prípade použitia hydrofilného gélu (karbopol), z ktorého množstvo uvol'neného liečiva bolo vy̌šsie ako z použitého komerčného gélu. Prítomnost’ mikroemulzie v karbopolovom géle nemala výrazný vplyv.

Acta Fac. Pharm. Univ. Comen. LIX, 2012, p. 81-88. 